\title{
Public Administration Education in a Legalistic Setting: New Tendencies in Hungarian Public Administration and Training
}

Márton Gellén

\begin{abstract}
The article examines the recent developments in public service training in Hungary and draws conclusions for the future. Hungary is considered to be part of the legalistic culture of European PA; therefore we analyze the connection between the legalistic approach as a cultural environment of PA practice and PA education as an influential factor of changing this environment. The empirical part of the research contains three elements: analysis of the professional training of civil service, the content of PA university training and the composition of professions within the central civil service. The empirical findings on these three dimensions are analyzed in light of recent structural changes of PA university education and professional training.
\end{abstract}

Under a Government Decree issued in 2012, the National University of Public Services was appointed by the Government to be in charge of PA education and training. The university itself was recently created by the merger of law enforcement, military and civil PA universities (academies). This structural change can be characterized by centralization and, to a certain extent, simplification, too. The restructuring of PA training is completed by the concept of the Government making the fields of public service permeable, open to each other. The university itself is a test field for this concept since police and military students have the opportunity to study civil PA courses. The need for this kind of cross-learning is supported by the new phenomenon that defense and policing are gradually becoming more civilian in their character, while traditional training in these fields must undergo serious changes too. Although the article states that the basic framework of public administration education - as a major driver of public administration culture - is still dominantly legalistic, it also introduces the ways in which the new public-administration education system has tried to change the content of its degree programs and how it 
has attempted to have an impact on the entire public-administrative system to move from procedural orientation to a more solution-oriented mindset.

\section{Key words:}

legalistic education, law, law and public administration, transition countries, regime change, Central and Eastern Europe, economic crisis

\section{Theoretical Background, Hungary as an Example for Legalistic PA Culture}

The $6^{\text {th }}$ Trans-European Dialogue conference in Potsdam, jointly organized by IIASEGPA (International Institute of Administrative Sciences - European Group of Public Administration) and NISPAcee, (Network of Institutes and Schools of Public Administration in Central and Eastern Europe) was partly dedicated to revisiting György Hajnal's findings after a 10-year period (Hajnal 2003 and 2013). Both studies stressed that Hungarian public-administration education belongs to the "legalistic" cluster within Europe. According to Hajnal (Hajnal 2013), Hungary and Germany as parts of the "legalistic" cluster did not change their orientation regarding PA education while other countries in the CEE region, like Slovakia, Slovenia or Romania, that belong to other PA education clusters with either policy or management orientation slightly changed the content of their PA education according to international trends.

Public-administration theory consistently classifies Hungary as part of the European continental, Weberian and legalistic culture. This applies both to PA practice and to PA education. Drechsler argues that in the case of Hungary the Weberian PA culture was able to stay alive throughout the years of communism (Drechsler 2005a, 99.) Drechsler also states that Weberian PA worked as a protective and supportive vehicle for the young democracy as well as for the new market economy (Drechsler 2005b). Legalism in PA might be seen as a factor that acts against broad policy and solution orientation. Therefore it is vital to examine whether the values of general PA and of legalism can be combined. Rechtsstaat culture is an intrinsic attribute to Hungarian public administration (Hajnal 2008, 132). Rechtsstaat culture in itself is definitely a positive factor and has been of high importance during the decades of the 1970s and 1980s. It represented a higher standard in comparison to the Soviettype administrative culture and as such - within narrow barriers - offered certain alternatives to the over-politicized operations of the Hungarian public administration. However, the content of naïve Rechtsstaat culture can be compressed in the slogan: "whatever is not explicitly allowed by law - is illegal". This thinking deeply affects public-administrative practice and can hardly be counterbalanced by unified interpretations of law promoted by administrative court decisions. Thus, during the communist period, distorted Rechtsstaat culture mixed with the traditional 
irresponsiveness of Soviet-type public administration resulted in a stiff and rigid combination. Legalistic PA culture has a decisive impact on the content of PA curricula as well as on the content of general PA practice. Consequently, the domestic interpretation of professionalism has been process- and regulation-oriented instead of result-oriented.

As more changeable times came in the 1990s and 2000s, the social and economic pressure for more efficacious and more flexible public administration increased. The public-administrative system reacted to this pressure in two dimensions: on the street level, a wave of contra legem practices made everyday life bearable (Gajduschek 2008, Hajnal 2008). On the macro level, the public-administrative system reacted with a constantly increasing amount of regulations: mostly modifications of the previous regulations but creating new legal material as well (Gellén 2012, 76).

\section{Composition of Professions in the Hungarian Central Public Administration}

In the following we analyze the composition of the Hungarian central PA regarding the proportion of civil servants with a background in law. We assume that the percentage of lawyers at an institution is an indicator of being legalistic. Diagram 1 shows that the proportion of lawyers is unequally distributed within central PA. It can be justified that lawyers are overrepresented at the Ministry of Public Administration and Justice and at the Ministry of Interior. The relatively high proportion of lawyers at the Ministry of Development though - which is in charge of transportation, energy, telecom, state-asset management and the allocation of EU funds - can be considered unexpected.

If the proportion of lawyers is analyzed according to age groups, we find that the percentage of civil servants with a law degree will even increase in the foreseeable future (see diagram 2). At the Ministry of PA and Justice, at the Ministry of Rural Development and at the Ministry of Development the number of young lawyers under 35 exceeds the number of more senior lawyers who are above the age of 35 . Consequently, the proportion of lawyers, and thus the influence of the lawyer profession, is expected to increase in these ministries. This may hinder the professionalization of central PA in terms of moving away from pure legalism to PA-values. Naturally, it can also be assumed that the thinking of lawyers employed as civil servants in the central public administration may change over time. Although such signs cannot be detected so far, professional training may broaden the intellectual perspectives of civil servants in the future. 


\section{Diagram 1}

Percentage of civil servants with a law degree within central PA

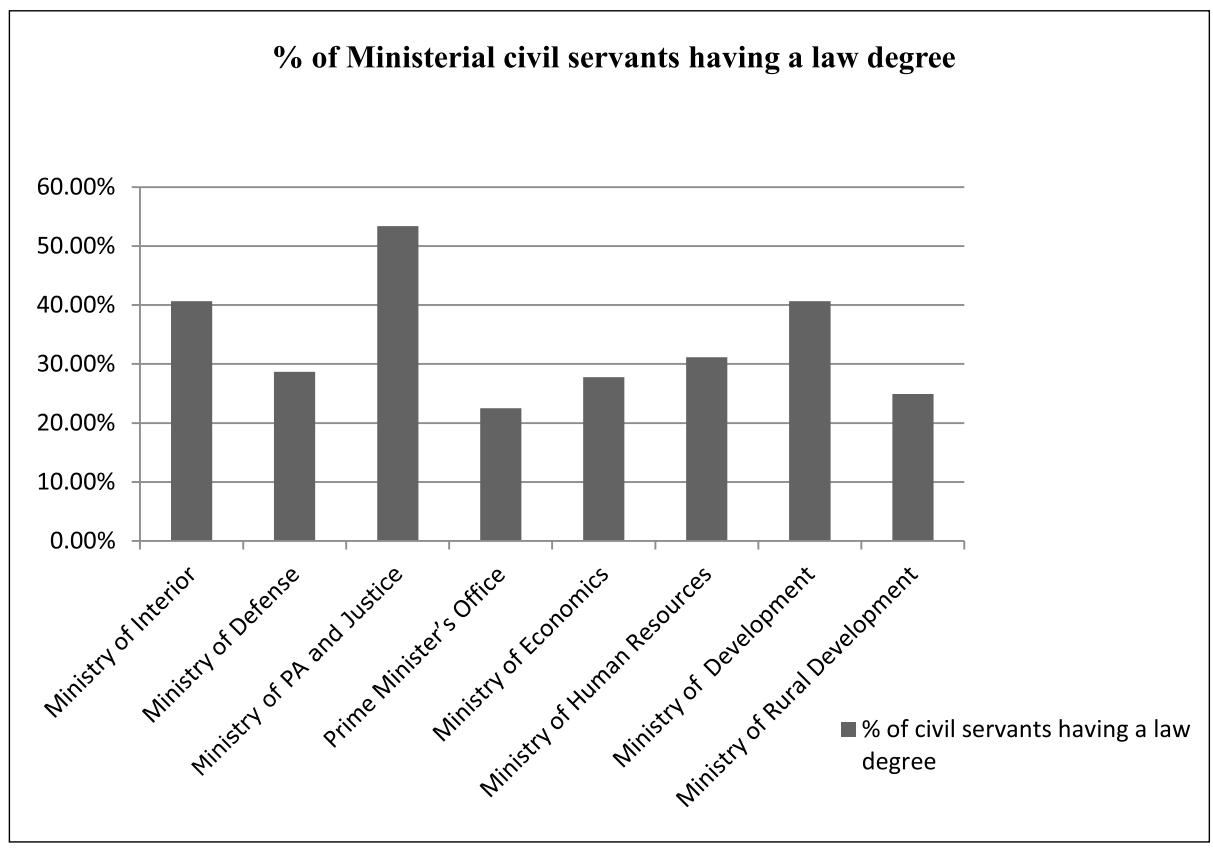

Source: KSZSZR $2012^{1}$

In order to indicate that the composition of the ministries is not entirely dominated by lawyers, Diagram 3 presents the proportion of ministerial civil servants having a university degree in economics or in management. The figures are significantly lower than the proportions of civil servants with law degrees, although at the Ministry of Economics the percentage of economists is somewhat above $51 \%$.

An interesting conclusion can be drawn from the three following ministries that might affect PA education, as well. These three ministries, constituting the Board of the National University of Public Service (NUPS), are the Ministry of Defense, the Ministry of Interior and the Ministry of Public Administration and Justice. All three ministries are dominated by lawyers. In the Ministry of Public Administration and Justice the percentage of lawyers is $53.36 \%$. This situation might cause a difficulty in the future if NUPS intends to increase the proportion of nonlegalistic PA (political science, public management or public-sector economics) in its curricula and to decrease the element of law.

1 KSZSZR is a Government database on civil service. 


\section{Diagram 2}

Comparing the proportion of lawyers under and above 35 years

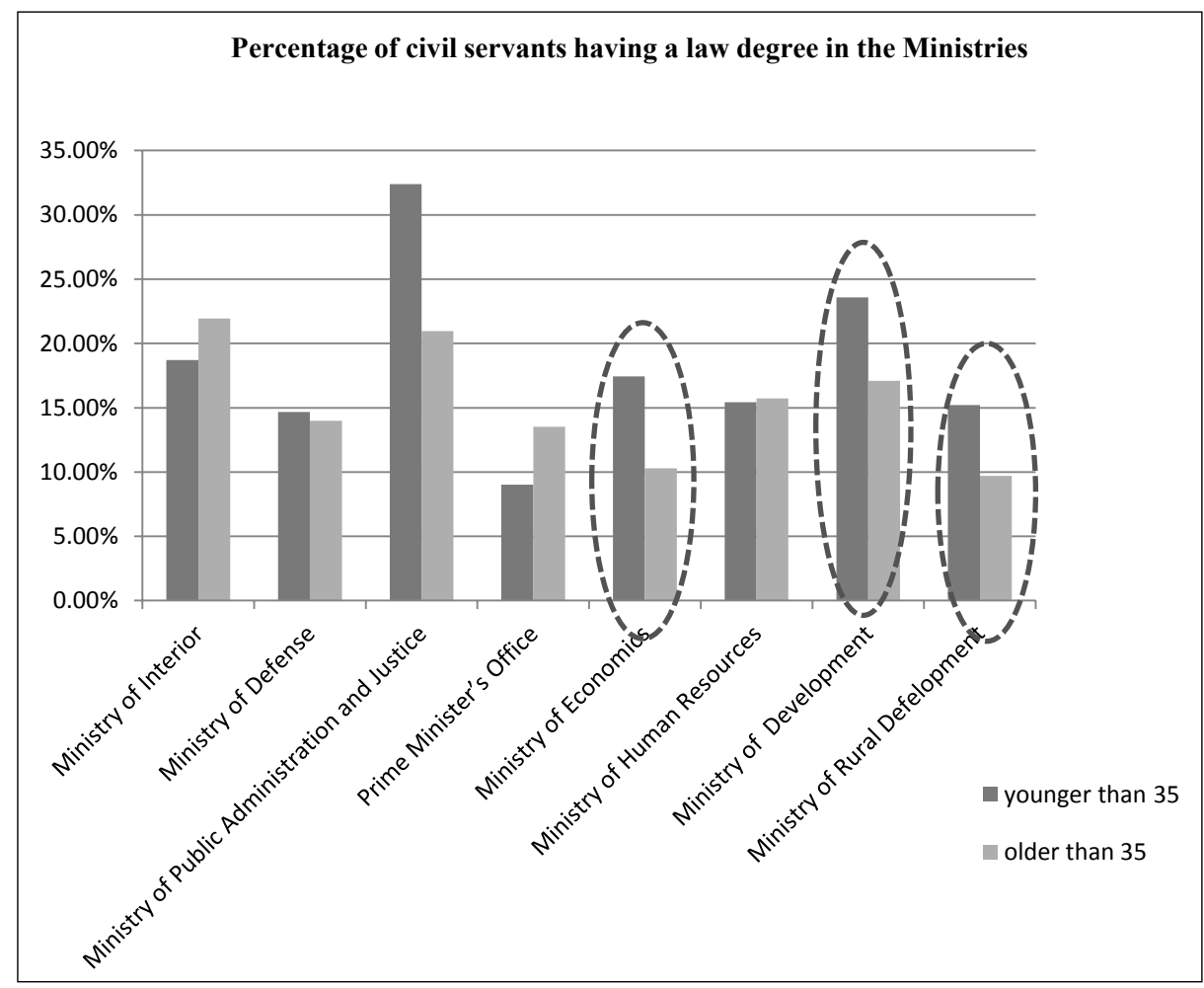

Source: KSZSZR 2012 


\section{Diagram 3}

Proportion of ministerial civil servants having a degree in economics or in management

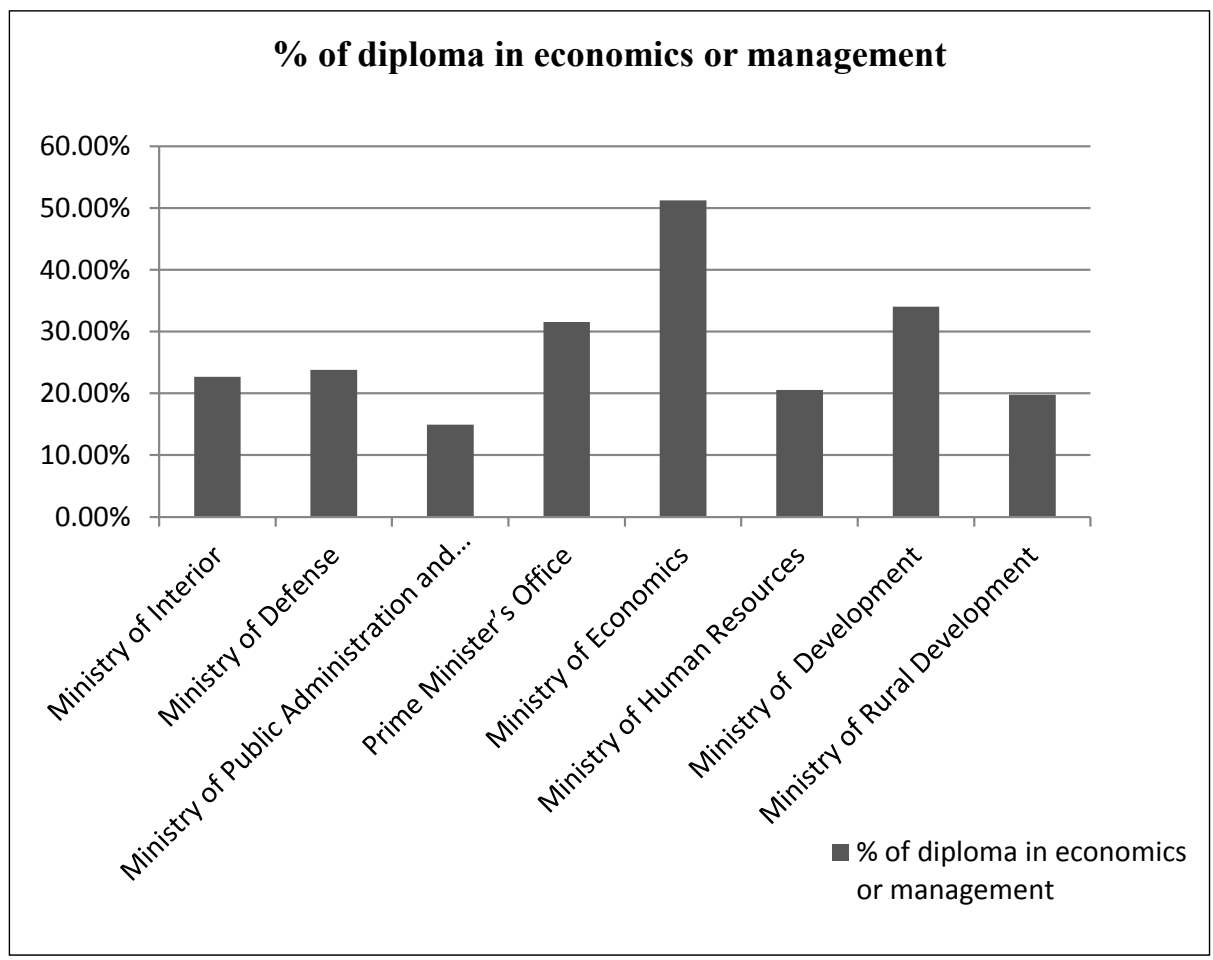

Source: KSZSZR 2012

\section{Brief institutional history of public-administration education in Hungary: PA education in a legalistic administrative culture}

\subsection{Historical heritage: Roots of a de-facto monopoly}

Traditionally, legal education and public-administrative education have been interwoven in Hungary. According to a law issued in 1883 (during the Monarchy of Austria-Hungary), the eligibility for higher positions in state administration was tied to having a law degree. In order to meet the personnel needs of the local administrations, an act was issued in 1900 that allowed the local notaries to be employed, requiring notary training only. In 1929 the diplomas of economics received equal state recognition as diplomas of law. Later, in 1934, university-level public-administration and economics education was established. In 1952 - in order to provide 
mid-cadres for the regime - Academies of the Soviets (Soviets meaning municipal and county administrations) were established with 5-months, later 10-months programs. From this stage throughout a number of institutional changes, a single Academy of the Soviets was created out of the remaining three institutions. The Academy of Public Administration was established in 1977. More recently, it was integrated into the Budapest University of Economics and Public Administration (today: Corvinus University) as a Faculty of Public Administration in 2000. In 2011 this Faculty was moved into the National University of Public Service where it became a Faculty of PA besides the Faculty of Law Enforcement (former Police Academy) and the Faculty of Defense (former University of Defense).

\subsection{Creating the National University of Public Service (NUPS)}

A PA education system based on a de-facto state monopoly definitely has an advantage: the state HR requirements can be relatively easily transformed into the curricula of degree programs or of professional trainings. Creating a university that is based on the concept of the unity of public service appears to be a unique approach since the university integrates the education of general public administration, law enforcement (policing) and military-officer education. However, from the polity perspective it may be rational. Hungarian military is very small compared to other NATO armies, for instance only 59 military officers graduated in 2008. Such modest demand by no means requires an entire university (thus the former military university used to offer a vast non-military portfolio). Regarding the HR needs of the police, Hungarian law enforcement always had the ambition of having a university-level education facility which was now realized within NUPS. From the polity point of view, civilian publicadministration education is also a beneficiary of the fusion since its financing appears to be more secure through the budgets of three ministries (Ministry of Public Administration and Justice, Ministry of Defense, Ministry of Interior), especially in times of a fiscal situation that deeply affects public university expenditures.

There is evidence that the three areas of public service came closer to each other than they were earlier: peace-keeping missions, emergency situations, logistics, IT security, social stability and many other fields could be mentioned where the three academic fields can be in synergy with each other. Until 2013 there was no doctorate school in general PA in Hungary. Potential Ph.D. aspirants in PA had to enter doctoral schools in either law, political science or one of the interdisciplinary doctoral schools. September 2013 will be the first time when a general PA doctoral school will be launched (within NUPS) in Hungary. Obtaining recognition for a not entirely legalistic doctoral program in PA first required convincing the National Accreditation Committee (dominated by lawyers) that PA as a discipline is different from the traditional legalistic image of PA. Due to considerable efforts the step was made, the accreditation process of a non-legalistic PA doctorate school succeeded. 


\subsection{Conclusions from institutional history: New opportunity of broadening horizons}

There are certain relevant conclusions that can be drawn based on this brief historic outline. First, the connection between the lawyer's profession and the civil service can be described as a delicate combination of contention and cooperation. PA graduates often continue their studies at a law faculty, faculty-of-law teachers often teach PA courses. Secondly, the historical overview shows that civil-service education (PA profession) always had an ambition to receive university-level recognition. This happened when PA education became part of the University of Economics (now: Corvinus), but this cohabitation could not result in a fruitful symbiosis. Since the legalistic content of PA education was not changed, the relatively small PA Faculty became gradually isolated within a vast, self-confident, market-oriented University of Economics.

It appears that large parts of the faculty of the University of Economics identified PA as an academic field different from economics and business. A similar perception could be observed in the relation between law and PA. While law and economics did not accept general PA as part of their intellectual realm, the PA discipline tried to identify itself by defining its relation to these two disciplines. However, PA discipline's attraction to law and to economics proved to be one-sided. Thus, PA had no other choice than to re-define itself as a unique discipline and profession. The driving institutional force in this effort is the National University of Public Service.

\section{Legalistic PA Education: What Does it Mean in Practice?}

\subsection{The Importance of NUPS}

The connection between the legalistic content of PA taught at NUPS (and at its predecessors) and PA practice (primarily at the central public administration) will be illustrated with a brief overview of what is taught in PA degree programs and through a content analysis of PA professional training. In order to underpin why we analyze the content of the PA programs of the National University of Public Services in detail, we indicate the current figures of general PA programs on the BA level.

General PA is taught at the following Hungarian institutions with the indicated capacity for the academic year beginning in September 2013. ${ }^{2}$

- National University of Public Services: 820 study places

- University of Debrecen, Faculty of Law: 25 study places

- University of Miskolc, Faculty of Law: 15 study places

- West Hungarian University, PA and Geo-information technology: 5 study places

- Péter Pázmány Catholic University, Faculty of Law: 15 study places.

2 Data provided by www.felvi.hu. 
This list covers only general PA programs. There are also other programs that have relevance in public-service or public-education training, like public-sector economics or public policy. These programs are also relatively small. As a comparison with clearly profiled PA programs is difficult, they are not indicated here. It can be seen that the PA programs of NUPS are so dominant on the domestic market that NUPS has a de-facto monopoly due to its heritage of institutional history. It can also be seen that three university faculties of law offer general PA programs with relatively low numbers of study places though.

\subsection{The content of PA education at the national champion}

Regarding NUPS as a national champion of PA education, the figures of PA degrees issued are as follows: $2011-448$ degrees, $2012-608$ degrees. The current total number of students at the Faculty of PA at NUPS covers 2291 students, including 155 non-degree students but excluding the participants of the professional trainings. If we compare the 2011 and 2012 figures with the number of vacancies advertised on the official website of the university admissions (www.felvi.hu) for 2013, a dynamic increase can be seen in terms of student headcounts on PA courses. This study does not have the capacity for a sociological research on the change of students' choices regarding PA. Nevertheless, as a vague hypothesis it can be assumed that the economic crisis might have had the impact of an increasing demand for a public-sector career in certain groups of the society.

In the PA curriculums, there are two main kinds of courses: obligatory and non-obligatory ones. At the beginning of every semester, a wide variety of nonobligatory courses are advertised, and the students can select a composition of their courses with the condition of collecting the necessary credits. The current two BA and two MA programs altogether offer 250 obligatory courses. If we exclude IT and language courses, there are still 230 courses from which we can form the categories below.

Table 1

Categories of obligatory courses in PA programs at NUPS

\begin{tabular}{|l|c|}
\hline \multicolumn{2}{|c|}{ Obligatory courses } \\
\hline Caw & Proportion \\
\hline Political science & $44.34 \%$ \\
\hline Economics \& management & $8.26 \%$ \\
\hline Other humanities & $33.47 \%$ \\
\hline
\end{tabular}


Among non-obligatory courses, the composition of the courses is different. Excluding language and IT courses, we get a total figure of 170 . The composition is as follows.

Table 2

Categories of non-obligatory courses in PA programs at NUPS

\begin{tabular}{|c|c|}
\hline \multicolumn{2}{|c|}{ Non-obligatory courses } \\
\hline Category & Proportion \\
\hline Law & $34.70 \%$ \\
\hline Political science & $25.29 \%$ \\
\hline Economics \& management & $12.34 \%$ \\
\hline Other humanities & $27.67 \%$ \\
\hline
\end{tabular}

"Law" includes theory of law, law enforcement, practical skills regarding law, EU and international law. "Political Science" includes theory of political science, history of politics, public policy, political communication. "Economics \& management" include public-sector economics and general economics, public and corporate management, finance, project management etc. "Other humanities" include social science, theory and practice of communications, psychology, culture.

As a conclusion to this brief content analysis of the PA education, provided by the dominant institution, it can be found that law as a discipline is still dominant among obligatory courses and is dominant - but not overwhelmingly - among nonobligatory courses. Since non-obligatory courses are subjects of students' choice, there is a certain competition among the courses offered. Since "political science" and "other humanities" have significantly higher representation among non-obligatory courses than among obligatory ones, it can be assumed that student interest considers "law" and "economics \& management" to be "hard" while "political science" and "other humanities" are to be "soft". According to this categorization, students prefer "soft" courses.

\subsection{Professional training}

Professional training is mandatory for all civil servants. There is an (basic) entrance exam and an advanced exam that is mandatory to pass regardless of being in a leadership position. Until 2011 civil-service professional training and the related mandatory examinations were coordinated by a government agency. By Act No. CXCIX of 2011 the professional training agency was integrated into the newly established NUPS regarding the entire civil service. The trainings regulated by the law contain the PA basic exam and the PA advanced exam. The PA basic exam has to be taken by each civil servant within one year after entering the civil service. It is a condition to pass the PA advanced exam in order to 
be promoted to the "counselor" grade, which is a significant career step after a few years in the civil service. The content of the PA basic exam and the content of the PA advanced exam are litmus tests regarding the official view on the necessary skills for the civil service. The brief content analysis of PA professional training - due to the recent institutional changes - mirrors the image of what the decision makers in charge of the curriculum have in mind regarding what professional attributes Hungarian Civil Servants should have. This observation offers a reference to Hajnal's 2013 finding, which stated that Hungary's position remained unchanged in the "legalistic cluster".

The currently available course book for the basic PA exam contains the following main chapters:

Table 3

Content of the basic PA exam Coursebook

\begin{tabular}{|l|l|}
\hline \multicolumn{1}{|c|}{ Title of main chapter } & \multicolumn{1}{|c|}{ Evaluation $^{4}$} \\
\hline I. Basics of law & $100 \%$ law (theory of law, constitutional law, basics EU law) \\
\hline II. Basics of PA & $\begin{array}{l}70 \% \text { PA, 30\% law (PA structure, HR, PA law, PA procedures, } \\
\text { PA development) }\end{array}$ \\
\hline III. Basics of the EU & $\begin{array}{l}70 \% \text { PA, 30\% law (EU in general, EU institutions, EU law, } \\
\text { Relation between EU law and domestic law) }\end{array}$ \\
\hline $\begin{array}{l}\text { IV. Introduction to public } \\
\text { finances and to public } \\
\text { financial management }\end{array}$ & $\begin{array}{l}90 \% \text { PA, 10\% law (Public-sector economics, state financing, } \\
\text { public-sector budgeting, state asset management, PA organs } \\
\text { under the central budget, public transfers, controlling and } \\
\text { auditing) }\end{array}$ \\
\hline $\begin{array}{l}\text { V. Basics of information } \\
\text { security and data } \\
\text { protection. }\end{array}$ & $\begin{array}{l}\text { 90\% law, 10\% PA (data-protection law, freedom of } \\
\text { information law, public-sector databases, law of classified } \\
\text { data) }\end{array}$ \\
\hline $\begin{array}{l}\text { VI. Institutional } \\
\text { administration }\end{array}$ & $\begin{array}{l}\text { 70\% law, 30\% PA (internal administrative proceedings, } \\
\text { internal institutional regulations, internal performance } \\
\text { management) }\end{array}$ \\
\hline
\end{tabular}

3 The Evaluation column indicates "PA" if the content of the subchapters includes public-sector economics, public policy, political science or public management (Coursebook 2012). 
The PA advanced exam contains the following main chapters:

Table 4

Content of the advanced PA exam Coursebook

\begin{tabular}{|l|l|}
\hline Title of the main chapter & \multicolumn{1}{|c|}{ Evaluation } \\
\hline $\begin{array}{l}\text { I. System of the central } \\
\text { public administration }\end{array}$ & $\begin{array}{l}100 \% \text { law (constitutional law, human rights, legal settings } \\
\text { of central PA, institutional law) }\end{array}$ \\
\hline $\begin{array}{l}\text { II. Legislation and } \\
\text { application of law }\end{array}$ & $\begin{array}{l}100 \% \text { law (theory of law, rule of law, legislative } \\
\text { procedure, application of law in general, PA procedures) }\end{array}$ \\
\hline III. General state finance & $\begin{array}{l}100 \% \text { PA (public-sector economics, public finances, } \\
\text { system of the central budget and of the social security, } \\
\text { local government budget, finances of public institutions, } \\
\text { control and auditing) }\end{array}$ \\
\hline $\begin{array}{l}\text { IV. Public-sector } \\
\text { management and leadership }\end{array}$ & $\begin{array}{l}\text { 90\% PA, 10\% law (leadership in general, managing an } \\
\text { institution, managing the administrative process, quality } \\
\text { management, HR and public-sector labor law) }\end{array}$ \\
\hline $\begin{array}{l}\text { V. EU institutions and EU } \\
\text { law }\end{array}$ & $\begin{array}{l}80 \% \text { PA, 20\% law (EU integration in general, EU law, } \\
\text { fundamental rights in the EU, institutional structure and } \\
\text { institutional operations of the EU, EU budgeting, EU } \\
\text { competencies and policies, Hungary in the EU) }\end{array}$ \\
\hline
\end{tabular}

The result of the brief analysis can be summarized in the following by aggregating the percentages:

- Basic PA exam - Law: $55 \%$, PA: $45 \%$

- Advanced PA exam - Law: $46 \%$ PA: $54 \%$

This method is only appropriate to compare the weight of the disciplines within the curriculum, the figures do not indicate any judgment on the internal values of the learning material. The content of professional training is deeply influenced by law. In the basic PA exam curriculum we find a dominantly legalistic interpretation of public administration. Regarding the advanced PA exam we can emphasize that legalistic content is dominant (see Hajnal's 2013 findings). The content of professional training has a major impact on the concept of what civil servants think of their own profession. This impact is indicated by the following figures: in 2012, the PA basic exam was taken by 2868 civil servants, while the PA advanced exam was taken by 1315 civil servants.

Professional training might be a decisive and obvious factor in increasing professionalization of Hungarian PA, especially central PA. However the dominance of legal discipline in the curriculum calls into question whether a swift change can be expected.

4 The Evaluation column indicates "PA" if the content of the subchapters includes public-sector economics, public policy, political science or public management (Coursebook 2012). 


\section{Teaching PA in a legalistic environment: But what is "legalistic"?}

Law itself underwent a serious change: civil-law orientation gradually gave way to public-law legislation in terms of quantities and in terms of the number of professionals of these fields within PA. This means that human behavior is increasingly the object of public law, which has the attribute of being imperative between parties of vertical relations. This is contrary to the approach of dispositive civil law that recognizes and protects the equality of partners. Public institutions organized to serve and to protect parties of civil-law relations require the ability of open understanding and arbitration (civil-law courts and ADRs for example). In case of public administrators, however, the legalistic approach is dominated by public law while the applied law tends to lack sensitivity and every-day law application appears to lose soft competencies that are inexorably part of the civil-law culture. The content of being "legalistic" is not purely related to trust in legal institutions or to the achievements of the rule of law, it is rather focused on a naïve Rechtsstaat culture. Administrative culture of this type takes law as a sheer transmitter of authoritative will to the society. This administrative culture can be called legalistic, but in content it is rather a positive law-driven system (Fisher 2000) than a rule-of-law system that is organically embedded within the society.

EU accession and EU law tended to even intensify the request for detailed imperative legislation in areas where civic self-regulation had ruled before (such as in household agriculture, which gave approximately one-third of the gross agricultural production of Hungary before the regime change). Legal imperativism deriving from the EU's need for legal cohesion and policy harmonization combined with the residues of the culture of obsequious behavior inherited from the communist era resulted in the significant retread of critical thinking in regulation and in decision-making within the PA.

The generational change of young administrators and the change in the shift from an arbitrary civil-law approach towards an imperative public-law approach are interlinked. The young civil servants of the last decade with a law degree were trained in the dynamic and promising age of the 1990s. Since new Hungarian and foreign private institutions of this decade were in extreme need of young lawyers (or PA graduates) with knowledge of foreign languages and the necessary knowledge of serving business, very few who had any affiliation with civil law chose public service as a career. Thus the composition of lawyers entering civil service became dominated by young lawyers who had a professional interest in public law instead of private law. This has an effect on the concept of law represented by lawyers within the civil service. They tend to represent a narrow, distorted interpretation of law, depriving it of the richness and of the flexibility of private law that contains the elements of mutuality and flexibility. The dominant interpretation of law is detected by Hajnal (2003 and 2013), Hintea-Ringsmuth-Mora (2006) and other scholars as "legalism". 
Will the new institutional framework of public-administration education and professional training be able to beneficially modify the stiff legalistic PA culture in Hungary? Based on the findings above, we can conclude the following: A de-facto national monopoly as a historical heritage might be a good institutional setting for doing quick reforms regarding the content of PA degree curricula and regarding professional training. It is also beneficial - from the perspective of the management of the reform - that professional training and education are deployed at the same institution. The content of education and training can only be gradually modified though. First the "market" of the young PA graduates has to be receptive to a more progressive attitude. It might be a risk to provide young professionals with managerial orientation for a legalistic administrative culture. The education should advocate policy effectiveness while reminding the students of the procedural necessities.

NUPS also has a management challenge. First of all it has a given heritage that can be built on but through major reforms in the content. What can be the drivers of reforming efforts? As it appears currently, the prime source of reforming curricula and education style is the institutional self-interest that relies on the need of selfdifferentiation from universities of law. Opportunities of promoting institutional interests are relatively obvious for a national champion. The financial position of NUPS - provided by defense, interior and justice\&PA budget - might be better than other public universities' finances, provided by the Ministry of Human Resources (prone to frequent austerities). The Governing Board of the University, delegated by three ministries is in the position of influencing reforms regarding PA education and training.

The notion of "legalistic" in PA education appears to be a notion to be further examined. "Legalistic" from my point of view reflects a Rechtsstaat-inspired image of law from which civil-law culture is largely removed. This means that the original balanced complexity of law is simplified in PA education to public-law culture. Hajnal's 2013 conclusions are valid, nevertheless it would be closer to the truth if we renamed the "legalistic" PA culture and education "public-law oriented" PA culture.

\section{References}

Drechsler, Wolfgang. 2005a. "The Re-Emergence of 'Weberian' Public Administration after the Fall of New. Public Management: The Central and Eastern European Perspective." Halduskultuur 6, 94-108.

Drechsler, Wolfgang. 2005b. "The Rise and Demise of the New Public Management." Post-Autistic Economics Review 33 (14 September 2005). Available at http://www.paecon.net/PAEReview/issue33/Drechsler33.htm (last accessed 21 April 2013).

Coursebook for Civil Service Basic Exam: http://www.nki.gov.hu/kepzesek-vizsgak/vizsgak/koezigazgatasi-alapvizsga 
Coursebook for Civil Service Advanced Exam: http://www.nki.gov.hu/kepzesekvizsgak/vizsgak/koezigazgatasi-alapvizsga

Fisher, Bruce D. 2000. "Positive Law as an Ethic: Illustrations of the Ascent of Positive Law to Ethical Status in the Commercial Sector." Journal of Business Ethics 25(2), 115-127.

Gajduschek, György. 2008. Rendnek lenni kellene: Tények és elemzések a közigazgatás ellenörzési és bírságolási tevékenységéröl. Budapest: KSZK.

Gellén, Marten. 2012. "Does Centralization Serve Efficiency? De-agencification in Hungary." NISPAcee Journal of Public Administration and Policy. Special Issue: The Politics of Agency Governance 5(2), 67-88.

Hajnal, György. 2013. "Re-visiting National Distinctiveness: A Survey of Public Administration Education in Europe." Presented at the Sixth Trans-European Dialogue in Public Administration (TED6), 6-8 February, Potsdam, Germany.

Hajnal, György. 2008. "Public Management Reforms: Hungary.” In Geert Bouckaert, Juraj Nemec, Vitalis Nakrošis, György Hajnal and Kristiina Tõnnisson (eds). Public Management Reforms in Central and Eastern Europe. Bratislava, Slovakia: NISPAcee Press, 121-150.

Hajnal, György. 2003. "Diversity and Convergence: A Quantitative Analysis of European Public Administration Education Programs." Journal of Public Affairs Education 9(4), 245-258.

Hintea, C., Ringsmuth, D. and Mora, C. 2006. "The reform of the higher education public administration programs in the context of public administration reform in Romania." Transylvanian Review of Administrative Sciences. (16), $40-46$. 